\title{
Familial Intrauterine Convulsions in Pyridoxine Dependency
}

\author{
MIR. BEJŠOVEC, Z. KULENDA, and E. PONČA \\ From the Children's Department, Central Laboratory, and Neurological Department of the \\ Regional Hospital, Usti nad Labem, Czechoslovakia
}

Pyridoxine dependency is a relatively rare congenital metabolic disturbance. To date 16 patients have been reported who survived (Schmidt, 1964), and probably 7 of their sibs died because the disease was not recognized in time. The present report concerns the first cases observed in Czechoslovakia.

Intrauterine convulsions are even rarer. Only two cases have been described (Badr-El-Din, 1960; Isler, 1964) and one mentioned in passing (Ford, 1960). Only one author (Badr-El-Din, 1960) mentions familial intrauterine convulsions, but there was no suggestion of a connexion between familial intrauterine convulsions and either congenital metabolic disturbance or pyridoxine dependency. For this reason we think our observations will be of interest.

The present report concerns three sibs, in all of whom the mother noted intrauterine convulsions: the first two died in status epilepticus. The third survived thanks to pyridoxine treatment, and biochemical studies were undertaken after birth.

\section{Case Reports}

Case 1. In 1962 a girl, A.B., was first seen at 1 month of age. She was the first child (first pregnancy) of healthy unrelated parents, in whom there was no relevant family history. The mother was well throughout pregnancy, but following the birth of the second child volunteered that she had been aware of abnormal paroxysmal movements before the birth of both the first 2 children. At birth the infant weighed $3400 \mathrm{~g}$. and measured $51 \mathrm{~cm}$. Delivery was normal, but breathing was difficult from the start, with intercostal recession during inspiration. After birth the child's condition kept changing; at times she was flaccid and the Moro reflex abolished, then she became irritable, agitated, and cried with an abnormal voice, and the extremities were held in abduction, so that the child looked as though it were crucified, the upper extremities in extension, the

Received July 4, 1966. lower in flexion. After a while irritability increased to such an extent that even the slightest touch provoked an exaggerated Moro reflex. This state progressed and developed into a series of regular lightning convulsions, repeated every five to seven seconds and preceded by an initial cry and followed by atony. In addition, the infant showed other paroxysmal phenomena: paroxysmal nystagmus in various directions, single rapid oscillations of the eye-balls, clonic or tonic-clonic convulsions, mostly unilateral but becoming generalized or alternating on the two sides; fast isolated muscular twitchings mostly of the face, eyes, and the upper extremities. During the convulsions the infant vomited and made masticatory movements, which were often unilateral, she became intensely pale and at times intestinal spasm could be observed through the abdominal wall. At first muscle tone was normal in the absence of convulsions, but later it increased to a state of rigidity of all four extremities.

For the first month periods of relative freedom from symptoms lasted up to several days. Later, however, for a few hours during the last few days before admission, lightning convulsions were present and resulted in pyrexia, the temperature reaching $39^{\circ} \mathrm{C}$. during the last few days of life. The EEG (Fig. 1) showed more or less regular episodes of spikes and slow waves followed by lowered and even extinguished electrical activity. The cerebrospinal fluid on the 12th day of life contained blood, and was later xanthochromic with an increased protein level to $92 \mathrm{mg} . / 100 \mathrm{ml}$. Ventriculography showed moderate symmetrical dilatation. Urinary and plasma electrolytes, blood sugar level, non-protein nitrogen, and tests for syphilis were normal. The infant died during the 7th week of life.

At necropsy the brain showed congestion and severe oedema, and on histological examination the leptomeninges were hyperaemic and infiltrated by numerous histiocytes and siderophages, but there were no signs of inflammation. It was concluded that the child had died from cerebral oedema, the underlying cause of which was not explained.

Case 2. In 1963, one year after her first delivery, the mother gave birth to a second female child, who died on the second day of life showing the same symptoms as the first. She weighed $3300 \mathrm{~g}$. and measured $50 \mathrm{~cm}$. at 


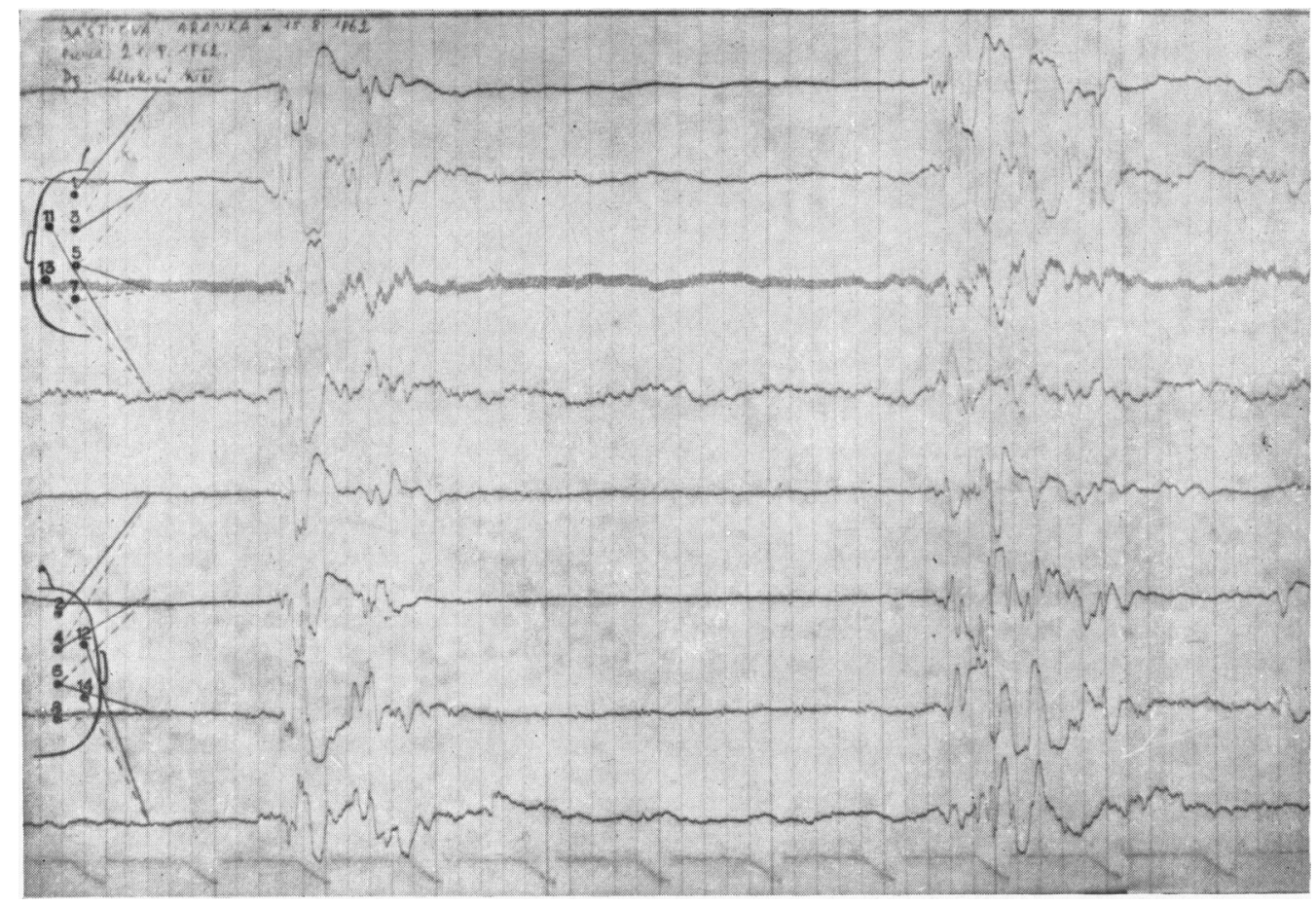

FIG. 1.-EEG of Case 1, showing more or less regular episodes of spikes and slow waves followed by lowered and even extinguished electrical activity.

birth, and delivery was normal. Some minutes after birth there was hyperirritability followed by twitching and lightning convulsions of the entire body accompanied by sharp cries and later by blood vomiting. She was admitted to the Prague Paediatric Clinic where she developed blood-stained vomiting and died on the second day. Necropsy revealed cerebral oedema, patchy atelectasis, and small gastric ulcerations. As pathogenic staphylococci were cultivated from the lungs, the liver, and the spleen, staphylococcal sepsis was diagnosed.

It was only during this second pregnancy that the mother became aware that in each case, at about the same time as the onset of normal foetal movements, she had repeatedly felt the same series of convulsive movements as she witnessed in both infants after birth. These usually occurred at the rate of 4 or 5 a minute, and consisted of repeated very intense twitching of the entire foetus. During these attacks normal movements ceased and only returned following an interval after the abnormal movements had stopped. The intrauterine convulsions were at irregular intervals, sometimes several times a day, but with the intervals of freedom of up to a fortnight. The mother maintained that she could confidently distinguish normal from abnormal movements, which at night would wake her up from sleep. She did not, however, mention them to the doctors but did tell her husband, who was also able to feel the movements through the abdominal wall. After her experience with the first child she claimed that she foresaw the disease in her second child. Though tests on the mother for toxoplasmosis were positive, and she had even been treated, this condition could be ruled out in her infants on the basis of the findings at necropsy.

Case 3. In spite of advice to the contrary, the mother became pregnant a third time and was seen again in November 1965 . From the 7th month of pregnancy she once again noted intrauterine convulsions and concluded that the third child would also be affected, and she was immediately admitted to hospital. EEG recordings of the foetus through the abdominal wall were not satisfactory. She was given $90 \mathrm{mg}$. of pyridoxine a day, but after two days the convulsive movements were repeated, and the dose was, therefore, increased to $110 \mathrm{mg}$. per day, when they stopped. Four days later, however, the mother went into labour and after a normal delivery gave birth to a male child. The infant weighed $3850 \mathrm{~g}$., and measured $52 \mathrm{~cm}$., with a head circumference of $39 \mathrm{~cm}$., and thoracic circumference of $35 \mathrm{~cm}$. There were the signs of increased irritability and setting-sun eyes. Percussion of the chin or eliciting the patellar reflex provoked tremors of the extremities, and the Moro reflex was exaggerated and combined with tremor. The EEG half an hour after birth was normal. The child was given $25 \mathrm{mg}$. pyridoxine daily in a single dose and the 
irritability disappeared, but reappeared on the next day before being given pyridoxine. On the fourth day the infant's reactions were normal and pyridoxine was experimentally withheld. Within two days there were alternating states of flaccidity and hyperirritability. The infant wrinkled his forehead, there was risus sardonicus and single rapid twitching eye movements. Four days after pyridoxine was omitted there were convulsions on the right and then on the left, myoclonic movements of the face and right arm, paroxysms of nystagmus in various directions, and the pulse rate rose to $200 / \mathrm{min}$., alternating with bradycardia. As the condition of the infant grew worse $50 \mathrm{mg}$. pyridoxine i.m. was given, followed by $80 \mathrm{mg}$. daily in four doses after which he did very well. At 3 months of age the child appeared to be normal except for slight generalized hypotonia. On January 1, pyridoxine was again omitted, and the course of events until it was resumed on January 9 , is depicted in Fig. 2. On the following day the hypotonia worsened, there were single twitches of the eye-balls and the infant stopped gaining weight. 9 days later slight clonic twitchings returned during sleep, and developed into convulsions of increasing frequency with outbreaks of explosive nystagmus. These lasted for about 5 minutes and were followed by transient hemiplegias, impairment of consciousness, pallor, and alternating tachycardia and bradycardia, at times almost amounting to cardiac arrest. In view of the child's condition, pyridoxine was no longer withheld. Within 5 minutes of the administration of $50 \mathrm{mg}$. i.m. the convulsions ceased, and after 15 minutes the muscle tone and the pulse rate returned to normal. After another dose in 4 hours the child's condition was normal.

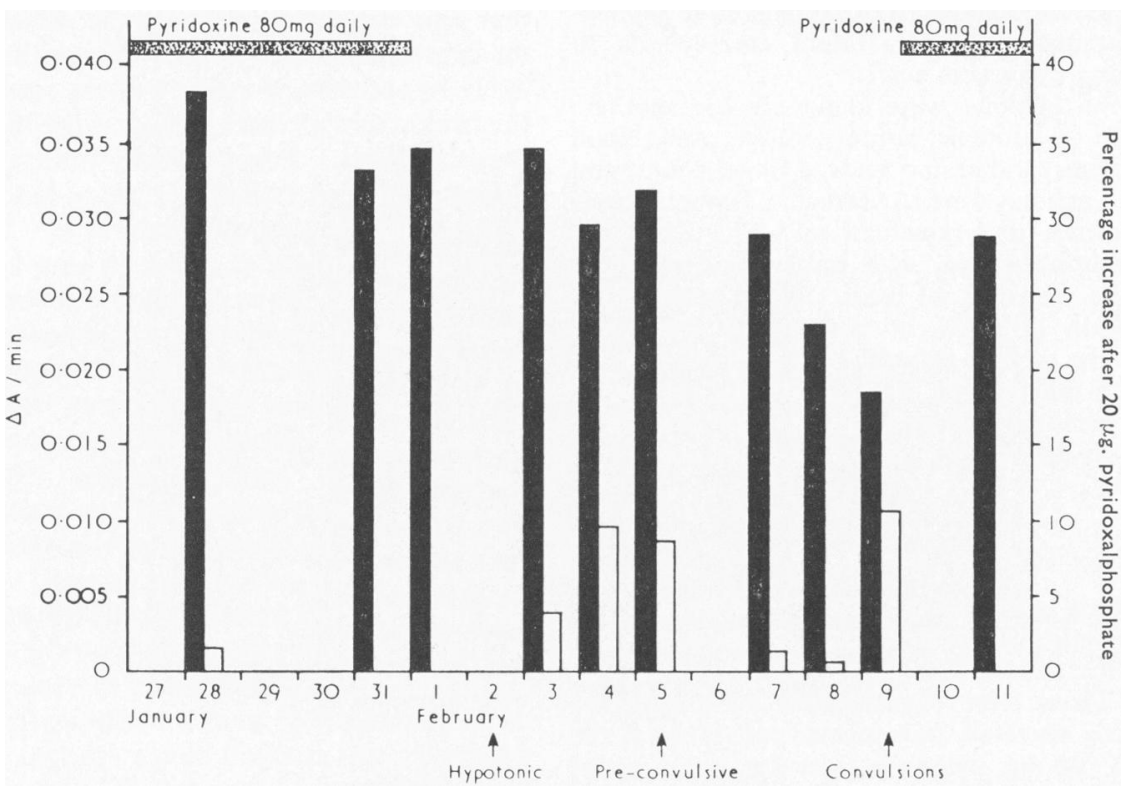

FIG. 2.-Effect of omitting pyridoxine on GOT activity of erythrocytes. The values for GOT activity of erythrocytes, expressed in delta A/min. are shown as black columns (left-hand scale). The degree of desaturation is expressed in the white columns, as the percentage increase in activity after adding $20 \mu \mathrm{g}$. pyridoxalphosphate in vitro (right-hand scale).
At the time of writing, the minimal effective dose is being established. He is receiving $30 \mathrm{mg}$. pyridoxine daily in three doses and is doing well. EEG recordings made at various times during eye twitching and various kinds of myoclonus showed deviation from the normal. We concluded that EEG tracings could not anticipate convulsions or the onset of serious clinical complications.

The child's toxoplasmosis test was positive, but faded gradually and was finally negative by the fourth month, and it was concluded that it was due only to placental transmission of maternal antibodies. Chromatographic examination of amino acids in the urine and the blood serum, with and without application of pyridoxine, urinary and plasma electrolytes, serum cholesterol, blood sugar, non-protein nitrogen, the blood picture, cerebrospinal fluid, and electrophoresis of serum proteins, were all normal.

Serum transaminases (Raica and Sauberlich, 1964) were examined in the blood serum by the method of Reitman and Frankel (1957). During application of pyridoxine they were slightly increased, the level being repeatedly between $(4 \cdot 3-5 \cdot 1 \mu$ Mole) $175-200$ Karmen units for GOT, and 110-140 Karmen units for GPT. Without pyridoxine the activity of GOT decreased to 47 Karmen units during the stage of convulsions, and that of GPT fell to 46 Karmen units.

The activity of erythrocyte GOT was estimated principally according to Baker, Canham, Nunes, Sauerlich, and McDowell (1964). Warburg's optic test was used. The optical density differences were measured at a wavelength of $340 \mathrm{~nm}$. in intervals of 1 minute for 10 minutes (Fig. 2). It can be seen that following the interruption of pyridoxine there was a gradual decrease 
in erythrocyte GOT activity. On the day of convulsions the values of this enzyme were $40-50 \%$ lower than during treatment and corresponded to the normal as found in healthy controls in whom activity was between 0.014 $0.022 \Delta \mathrm{A} / \mathrm{min}$. The values at the time of compensation owing to pyridoxine must, therefore, be considered raised. The changes in GOT and GPT activity in the blood serum and the erythrocytes correspond, though the investigations were carried out by two different methods and examiners.

The examination of GOT activity in the erythrocytes after the addition of pyridoxalphosphate in vitro is a sensitive indicator of pyridoxine deficiency (Baker et al., 1964). This examination showed that there was complete saturation of the apoenzyme of erythrocyte GOT during treatment. Examination after suspension of treatment showed deficiency of saturation of apoenzyme, particularly during the period of clinical deterioration. It corresponded to values found in the controls. After the addition of pyridoxalphosphate in vitro activity increased, though not, however, to the level found during pyridoxine treatment. From this it could be concluded that pyridoxine applied in high doses not only caused complete saturation of transaminase by coenzyme but also increased the apoenzyme level.

The tryptophan test was performed three times. Tryptophan metabolites were proved by chromatography (Dalgliesh, Knox, and Neuberger, 1951). The chromatograms were evaluated visually at $253 \cdot 7 \mathrm{~nm}$. (O'Brien, and Ibbot, 1956). Results were negative twice, but on the third occasion, on the day of convulsions, there was a noticeable slight increase in the excretion of the compound with $R_{f} 0.6$ found by comparing urine samples taken before and after application of tryptophan. The $R_{f}$ found corresponds to xanthurenic and kynurenic acid.

Various investigations were done on the mother: electrophoresis of proteins, urine analysis, and blood serum electrolytes, and amino acids, a blood count, and Wassermann reactions, were all normal. Toxoplasmosis tests were positive and remained so. The EEG was perhaps slightly abnormal, with some dispersed theta and even delta waves in all leads. EEG examination after application of INH in therapeutic doses was planned, but the mother refused. In both parents the speed of INH inactivation was tested. In the father values were obtained corresponding to the usual slow inactivation; in the mother, however, inactivation was unusually slow.

\section{Clinical Summary}

The beginning of the disease consisted of intrauterine convulsions starting in the first two children during the 5 th, and in the third child during the 7th, month of pregnancy. These were characterized by a series of single, regularly repeated, very intense twitchings of the whole foetus. $90 \mathrm{mg}$. pyridoxine per day, given to the mother, did not eradicate these convulsions, though they ceased after $110 \mathrm{mg}$. The most striking clinical feature was the alternation of hypo- and hyper- irritability in all children, becoming increasingly regular and frequent and finally developing into an alternation of lightning convulsions and atony. In the third child there were no lightning convulsions because pyridoxine treatment was always instituted in time from fear of irreversible damage. The minimum effective dose has not yet been found. With $30 \mathrm{~g}$. daily in three doses the child is symptom free. The first child died without specific treatment after 7 weeks, and the second child on the second day of life. Anticonvulsive treatment was without any effect. Pyridoxine administered parenterally to the third child was effective within a few minutes.

Biochemical examination was in the main negative. EEG during a series of lightning convulsions in the first child showed the typical pathological pattern. In the third child it proved non-informative, as it did not give any warning of imminent convulsions. The main relevant necropsy finding in the first two children was severe cerebral oedema.

\section{Discussion}

Pyridoxine, transformed in the body into active pyridoxalphosphate, is an important coenzyme of many biochemical reactions. Its lack causes a disturbance in tryptophan metabolism (Bower, 1965; Cramer, 1962; Dahler, 1963; Hellström and Vassella, 1962; Hottinger, Berger, and Krauthammer, 1964), with an increased excretion of xanthurenic acid which can easily be established. Since, however, in pyridoxine dependency, no changes have been found even in tryptophan metabolism, it has been suggested that the enzymatic disturbance affects exclusively the central nervous system. According to the most likely hypothesis, $\gamma$-aminobutyric acid is formed in the brain from glutamic acid, by the aid of a specific decarboxylase. From $\gamma$-aminobutyric acid the amino group is transferred to $\alpha$-ketoglutaric acid which changes into glutamic acid. In both cases pyridoxalphosphate is required as a coenzyme. A disturbance of these reactions probably plays an essential role in pyridoxine dependency. The exact site of the disturbance is, however, as yet unknown.

We believe that the increased values of transaminase in the plasma and the intercellular fluid found in our patient during treatment with pyridoxine were a consequence of vitamin treatment because, after interruption of this treatment, transaminase activity returned to normal. According to our findings this increased activity was caused not only by complete saturation with the apoenzyme of pyridoxalphosphate but by its increase, as the values of enzyme activity in the erythrocytes 7 days after treatment was stopped never reached the level they had before treatment, even when large quantities of pyridoxalphosphate were added in vitro. This may be explained as a feedback effect of pyridoxal- 
TABLE

Summary of Cases of Pyridoxine-dependency Which Survived

\begin{tabular}{|c|c|c|c|c|c|c|}
\hline $\begin{array}{l}\text { Case } \\
\text { No. }\end{array}$ & Reference & $\begin{array}{l}\text { Onset of } \\
\text { Convulsions }\end{array}$ & $\begin{array}{l}\text { Onset of } \\
\text { Therapy }\end{array}$ & $\begin{array}{c}\text { Minimal } \\
\text { Dose (mg.) }\end{array}$ & $\begin{array}{l}\text { Clinical } \\
\text { Condition }\end{array}$ & Remarks \\
\hline 1 & Hunt et al. (1954) & 3 hours & 7 months & 2 & Retarded & $\begin{array}{l}\text { Mother on pyridoxine during } \\
\text { pregnancy for hyperemesis; } \\
\text { familial }\end{array}$ \\
\hline 2 & $\begin{array}{c}\text { Bessey, Adam, and } \\
\text { Hansen }(19 j 7)\end{array}$ & 1st month & 8th month & 2 & Retarded & Tryptophan test positive \\
\hline $\begin{array}{l}3 \\
4 \\
5 \\
6\end{array}$ & $\begin{array}{l}\text { Bessey et al. (1957) } \\
\text { Marie et al. (1959) } \\
\text { Scriver (1960) } \\
\text { Denève and } \\
\text { Yongbloet (1961) }\end{array}$ & $\begin{array}{l}\text { 3rd day } \\
5 \text { th day } \\
7 \text { th day } \\
13 \text { th day }\end{array}$ & $\begin{array}{l}\text { 8th day } \\
\text { 2nd month } \\
\text { 8th day } \\
\text { 17th day }\end{array}$ & $\begin{array}{r}2 \\
4 \\
10 \\
5\end{array}$ & $\begin{array}{l}? \\
\text { Retarded } \\
\text { Normal } \\
\text { Normal }\end{array}$ & $\begin{array}{l}\text { Administration of GABA }{ }^{\star} \text {, familial } \\
\text { Familial } \\
\text { Therapy interrupted after } 3 \mathrm{mth} \text {; } \\
\text { observed for } 2 \mathrm{yr} \text {. }\end{array}$ \\
\hline 7 & $\begin{array}{l}\text { Nordio, Segni, } \\
\text { de Pra, and } \\
\text { Lojodice }(1961)\end{array}$ & 8th day & 8th day & 40 & Normal & Familial \\
\hline 8 & Garty et al. (1962) & 4 hours & 11 th day & 2 & Normal & $\begin{array}{l}10 \text { pregnancies, } 3 \text { ended with } \\
\text { abortion, } 2 \text { died within } 3 \text { mth. of } \\
\text { birth }\end{array}$ \\
\hline $\begin{array}{r}9 \\
10\end{array}$ & $\begin{array}{l}\text { Marie et al. }(1961) \\
\text { Zunin and } \\
\quad \text { Vallarino (1963) }\end{array}$ & $\begin{array}{l}4 \text { th day } \\
\text { ? }\end{array}$ & $\begin{array}{c}\text { 4th day } \\
\text { ? }\end{array}$ & $\stackrel{4}{?}$ & $\begin{array}{l}\text { Normal } \\
?\end{array}$ & $\begin{array}{l}\text { Sib mentioned above, Case } 4 \\
\text { Was not at our disposal }\end{array}$ \\
\hline 11 & $\begin{array}{l}\text { Waldinger and } \\
\text { Berg (1963) }\end{array}$ & At birth & & 10 & Retarded & Familial; author presumes existence \\
\hline 12 & $\begin{array}{l}\text { Waldinger and } \\
\text { Berg (1963) }\end{array}$ & At birth & At birth & 12 & Normal & of intrauterine onset of disease \\
\hline 13 & Schmidt (1964) & 1 hour & 3rd day & 60 & Normal & $\begin{array}{l}\text { Mother suffered from polyneuritis } \\
\text { during pregnancy; child was } \\
\text { treated with pyridoxine for } 2 \text { mth. } \\
\text { only }\end{array}$ \\
\hline 14 & $\begin{array}{l}\text { French et al. } \\
\quad(1965)\end{array}$ & 28 hours & 5th month & $6 \mathrm{mg} \cdot / \mathrm{kg}$. ? & & \\
\hline 15 & $\begin{array}{l}\text { Scriver and } \\
\text { Cullen (1965) }\end{array}$ & 3rd month & 11th month & 10 & Normal & $\begin{array}{l}\text { Hyperirritability with occasional } \\
\text { convulsions; under observation } \\
\text { for } 7 \text { yr. }\end{array}$ \\
\hline $\begin{array}{l}16 \\
17\end{array}$ & $\begin{array}{l}\text { Robins }(1966) \\
\text { Our case }(1966)\end{array}$ & $\begin{array}{l}\text { At birth } \\
\text { Intrauterine }\end{array}$ & $\begin{array}{l}\text { 1st month } \\
\text { Pyridoxine } \\
\text { given to } \\
\text { mother } \\
\text { before } \\
\text { delivery }\end{array}$ & $\begin{array}{l}10 \\
20\end{array}$ & $\begin{array}{l}\text { Normal } \\
\text { Small } \\
\text { degree of } \\
\text { retardation }\end{array}$ & $\begin{array}{l}\text { Familial } \\
2 \text { sibs died with 'lightning } \\
\text { convulsions'; mother felt } \\
\text { intrauterine convulsions during all } \\
3 \text { pregnancies }\end{array}$ \\
\hline
\end{tabular}

Note: In only two cases was it possible to leave off the pyridoxine therapy. Tryptophan test was normal except in one case. EEG patterns became normal with the administration of pyridoxine, in a few minutes. Hyperirritability was present in all cases before the onset of convulsions. In addition to these 17 surviving cases of pyridoxine dependency, 9 sibs from 7 of these families died, in all probability of pyridoxine dependency. $\star$ Gamma aminobutyric acid.

phosphate on the production of apoenzyme. From our findings it appears unlikely that any part is played by a competitive inhibitor in the pathogenesis of the disease or by a disturbance of phosphorylation of pyridoxine. Therefore, it is as yet difficult to say how important transaminase activity is in determining the state of the patient and the correct dose of pyridoxine to be given. In our case a decrease in saturation was accompanied by clinical deterioration and even by convulsions.

Pyridoxine dependency was first described by Hunt, Stokes, McCrory, and Stroud, in 1954 and by Hunt in 1957. We found 16 more cases in the literature; 7 of their sibs also died under similar conditions (Table). The beginning of the disease may appear in the form of intrauterine convulsions, as shown in our cases. Waldinger and Berg (1963), Waldinger (1964), and Robins (1966) described the first signs during normal delivery as consisting mainly of breathing disorders and hyperirritability. The majority of authors (Marie, Hennequet, Lyon, Debris, and Le Balle, 1961; Nordio, Segni,
Romano, and Grossi Bianchi, 1962; Scriver, 1960; Scriver and Hutchison, 1963) described the first convulsions during the first hours or days after birth: they are preceded by hyperirritability. It is exceptional for convulsions to be observed during later months (French, Grueter, Druckman, and O'Brien, 1965; Scriver and Cullen, 1965). The course is usually progressive and without treatment is fatal within a few weeks. In two cases treatment was interrupted without any harm to the child. Only one author described a benign non-lethal form with hyperirritability and epileptic convulsions, which could be easily managed by administration of $10 \mathrm{mg}$. pyridoxine per day (Scriver and Cullen, 1965). If pyridoxine is administered in a sufficient dose it stops both convulsions and EEG changes within a few minutes, and within a few hours all abnormality ends. The minimum effective dose varies from case to case, from 2 to $80 \mathrm{mg}$. per day. Marie et al. (1961) was the only author who used $\gamma$-aminobutyric acid instead of pyridoxine i.v. for the treatment of the convulsions. The first time it 
had a good effect which, however, did not last so long as that of pyridoxine; the second time the effect was less, and the third time there was no effect at all. This therapeutic experiment, however, as well as other circumstances, supports the hypothesis that pyridoxine dependency is a congenital metabolic disturbance of the glutamic acid circle. The benign case of Scriver and Cullen (1965) and two more cases (Schmidt, 1964), in which it was possible to stop pyridoxine treatment after a certain period, point to the possibility that in addition to severe, probably homozygotic, cases there also exist mild cases, perhaps heterozygotes, which might become clinically apparent only under some extraordinary circumstances. This might explain why neuropathy developed in a few rare cases treated with isoniazid (INH), an antipyridoxine compound, because it blocks pyridoxine phosphorylization. Convulsions observed in a small number of artificially fed infants treated with suboptimal doses of pyridoxine during the 'pyridoxine deficiency epidemic' in the U.S.A. in the years 1950-54 (Holtz and Palm, 1964) may also be explained in this way. We suggest that in doubtful cases of seizures in young infants, the administration of some anti- pyridoxine, of which INH is perhaps the best, might bring out, at least on the EEG tracings, latent pyridoxine dependency. At present we can only point out that the mother of our patient was an abnormally slow inactivator of INH.

Intrauterine convulsions have very rarely been described. In his textbook Ford (1960) mentions only two cases during the seventh month of pregnancy, probably caused by anoxia. The most interesting observations and the most similar to our own are familial intrauterine and lightning convulsions, as described by Badr-El-Din (1960). He reported an infant girl with repeated convulsions, generalized hypertonus, and flexion rigidity immediately after birth. Percussion on her chin or anywhere else evoked a shock-like reflex extension of both upper and lower extremities. The convulsions started with a cry followed by risus sardonicus and clonic convulsions lasting for about 30 seconds. This again was followed by complete atony. This child's parents were first cousins, and furthermore, two of the mother's sisters married two of the father's brothers. In these three consanguineous families 21 children were born of whom 8 suffered from the same symptoms as described. The mothers knew about the intrauterine convulsions and were therefore able to predict which of the children would be normal and which abnormal after birth. The disease was not sex-linked, it was progressive, and all the affected children died soon after birth. Badr-El-Din's own case in this family lived the longest, dying in status epilepticus at 16 months, at which time her development was retarded and she was able only to sit up and pronounce one or two badly articulated words. No necropsy was performed. Badr-El-Din reached the conclusion that this was a case of a recessive autosomal disease. In his discussion the possibility of a metabolic disorder is not mentioned, but in view of our own observations we suggest that the underlying disorder was an inborn metabolic error, possibly pyridoxine dependency.

Intrauterine convulsions are probably not as rare as the literature would suggest, but are not detected because they are not sought for. It is also necessary to differentiate convulsions from foetal hiccup characterized by regular movements of small intensity at a frequency of 1 to 3 in 10 seconds. Clonic convulsions as described by Isler are characterized by regular very intense movements of the foetus at the rate of about 2 per second. Series of lightning convulsions as in our cases, and as we assume them in Badr-El-Din's case, are characterized by single foetal twitches several times a minute. The mother recognizes them mainly by the very regular and very intense movements of the foetus. The mother of our case also stressed that during the period of convulsions no normal movements were felt. For objective recording, the kymograph used by Dietel and Dietel (1959) for registration of breathing movements and foetal hiccup could serve, as well as EEG through the abdominal wall.

Our observations prevent us from agreeing with the otherwise very important work of Bernard, Kaiser, and Kolmodin, who in 1962 asked why no intrauterine convulsions were described; on the basis of experiments with sheep foetus they reached the opinion that though paroxysmal activity can be found in the brain no convulsions can be seen, because the descending spinal tracts are not yet developed.

Our latest case proves that intrauterine convulsions are not as rare as supposed. A boy, with a similar clinical picture to the one described above, recovered after pyridoxine treatment; in addition, however, hypocalcaemia and hypomagnesia were found. At a later stage the child no longer required pyridoxine treatment, even after provocation with INH. The diagnosis of this case has not yet been finally settled.

\section{Summary}

Intrauterine convulsions are described in three sibs, the third of which was shown to be pyridoxinedependent. The first child died after 7 weeks and the second the day after birth, in a state of lightning 
convulsions (infantile spasms). The third, a boy, survived. This appears to be the first case of intrauterine pyridoxine-dependent convulsions to be described.

The intrauterine convulsions ceased when pyridoxine was given to the mother, but returned after the infant was born, on three occasions.

During treatment serum and erythrocyte transaminase were increased and returned to normal values when pyridoxine was discontinued. Saturation of erythrocyte GOT with pyridoxalphosphate was complete during treatment and partial desaturation occurred during convulsions. The values of desaturation, however, corresponded to the values found in controls.

The clinical picture was of a striking alternation of hypo- and hyperirritability and repeated lightning convulsions.

It is suggested that pyridoxine dependency should be born in mind in families with abortions and stillbirths, and particularly if a woman reports convulsive intrauterine foetal movements, or when unexplained convulsions occur soon after birth. In these cases it is worth trying pyridoxine in a dose of $300 \mathrm{mg}$. daily to the mother or $50 \mathrm{mg}$. to the infant; in the case of pyridoxine dependency immediate recovery takes place.

The possibility of abortive forms of pyridoxine dependency in heterozygotes and of tracing them with the aid of antipyridoxines is briefly mentioned.

\section{REFERENCES}

Radr-El-Din, M. K. (1960). A familial convulsive disorder with an unusual onset during intrauterine life. A case report. $\mathcal{f}$. Pediat., 56, 655.

Baker, E. M., Canham, J. E., Nunes, W. T., Sauerlich, H. E., and McDowell, M. E. (1964). Vitamin B6 requirement for adult man. Amer. F. clin. Nutr., 15, 59.

Bernard, C. G., Kaiser, I. H., and Kolmodin, G. M. (1962). On the epileptogenic properties of the fetal brain: an electrophysiological study on the electrically and chemically induced convulsive brain activity in sheep fetuses. Acta paediat. (Uppsala), 51, 81.

Bessey, O. A., Adam, D. J. D., and Hansen, A. E. (1957). Intake of vitamin B6 and infantile convulsions: a first approximation of the requirements of pyridoxine in infants. Pediatrics, 20, 33.

Bower, B. D. (1965). Pyridoxine, tryptofan and epilepsy. Develop. Med. Child Neurol., 7, 73.

Cramer, H. (1962). Die Pyridoxine-abhängigen Sauglingskrämpfe. Ein metabolisch-genetisches Anfallsleiden. Dtsch. med. Wschr., 87, 1577.

Dahler, R. P. (1963). Untersuchungen über den TryptophanAbbau und den Vitamin B6 Stoffwechsel beim Neugeborenen und beim Säugling. Ann. paediat. (Basel), 200, 346.

Dalgliesh, C. E., Knox, W. E., and Neuberger, A. (1951). Intermediary metabolism of tryptophan. Nature (Lond.), 168, 20.

Denève, V., and Yongbloet, P. (1961). Convulsies in de neonatale periode beinvloedbaar door pyridoxine. Maandschr. kindergeneesk., 29, 177.

Dietel, K., and Dietel, V. (1959). Úber den Singultus bei intrauterinen Atembewegungen. Kinderärztl. Prax., 27, 453.

Ford, F. R. (1960). Diseases of the Nervous System in Infancy, Childhood and Adolescence, 4 th ed., p. 1084. Charles C. Thomas, Springfield, Illinois.

French, J. H., Grueter, B. B., Druckman, R., and O'Brien, D. (1965). Pyridoxine and infantile myoclonic seizures. Neurology (Minneap.), 15, 101.

Garty, R., Yonis, Z., Braham, J., and Steinitz, K. (1962). Pyridoxine-dependent convulsions in an infant. Arch. Dis. Childh., 37, 21.

Hellström, B., and Vassella, F. (1962). Tryptophan metabolism in infantile spasm. Acta paediat. (Uppsala), 51, 665.

Holtz, P., and Palm, D. (1964). Pharmacological aspects of vitamin B6. Pharmacol. Rev., 16, 113.

Hottinger, A., Berger, H., and Krauthammer, W. (1964). Klinische Beobachtungen zum Problem des vitamin-B6Metabolismus. Schweiz. med. W'schr., 94, 221.

Hunt, A. D. (1957). Abnormally high pyridoxine requirement. Summary of evidence suggesting relation between this finding and clinical pyridoxine 'deficiency'. Amer. F. clin. Nutr., 5, 561 . , Stokes, J., McCrory, W. W., and Stroud, H. H. (1954). Pyridoxine dependency: report of a case of intractable convulsions in an infant controlled by pyridoxine. Pediatrics, 13, 140.

Isler, W. (1964). Fötale epileptische Anfälle. Mitteilung eines Falles. Helv. paediat. Acta, 19, 318.

Marie, J., Hennequet, A., Lyon, G., Debris, P., and Le Balle, J. C. (1959). Les crises convulsives pyridoxino-sensibles du nouveau né et du nourrison. Sem. Hôp. Paris, 35, 1411.

,,,--- and - (1961). La pyridoxino-dépendance, maladie métabolique s'expriment par des crises convulsives pyridoxino-sensibles. (Première observation familiale.) Rev. neurol., 105, 406.

Nordio, S., Segni, G., de Pra, M., and Lojodice, G. (1961). Convulsioni pirridossino-dipendenti. Primo contributo della letteratura italiana. Minerva pediat., 13, 925.

- - Romano, C., and Grossi Bianchi, M. L. (1962). Seltene Krankheiten, die einer Bahandlung mit Pyridoxin zugänglich sind. Mschr. Kinderheilk., 110, 116.

O'Brien, D., and Ibbot, F. A. (1956). Laboratory Manual of Pediatric Micro and Ultramicro Biochemical Techniques. Univ. Colorado Med. Center Press, Denver.

Raica, N., and Sauberlich, H. E. (1964). Blood cell transaminase activity in human vitamin B6 deficiency. Amer. F. clin. Nutr., $15,67$.

Reitman, S., and Frankel, S. (1957). A colorimetric method for the determination of serum glutamic oxalacetic and glutamic pyruvic transaminases. Amer. F. clin. Path., 28, 56.

Robins, M. M. D. (1966). Pyridoxine dependency convulsions in a newborn. F. Amer. med. Ass., 195, 491.

Schmidt, E. (1964). Zum Krankheitsbild der Vitamin B6(Pyridoxin)-Abhängigkeit bei Neugeborenen. Z. Kinderheilk., 89, 211

Scriver, C. R. (1960). Vitamin B6-dependency and infantile convulsions. Pediatrics, 26, 62.

—, and Cullen, A. M. (1965). Urinary vitamin B6 and 4pyridoxic acid in health and in vitamin $\mathrm{B} 6$ dependency. ibid., 36, 14.

- , and Hutchison, J. H. (1963). The vitamin B6 deficiency syndrome in human infancy: biochemical and clinical observations. ibid., 31, 240.

Waldinger, C. (1964). Pyridoxine deficiency and pyridoxine dependency in infants and children. Postgrad. Med., 35, 415.

, and Berg, R. B. (1963). Signs of pyridoxine dependency manifest at birth in siblings. Pediatrics, 32, 161.

Zunin, C., and Vallarino, G. (1963). Le crisi convulsive sensibili alla piridossina: presentazione di uno caso. Minerva pediat., 15, 975. 